\title{
EPISODES OF GUILLAIN-BARRÉ SYNDROME ASSOCIATED WITH THE ACUTE PHASE OF HIV-1 INFECTION AND WITH RECURRENCE OF VIREMIA
}

\author{
Gleusa de Castro', Patrícia Gomes Bastos², Roberto Martinez', \\ José Fernando de Castro Figueiredo ${ }^{1}$
}

\begin{abstract}
We report a severe case of Guillain-Barré syndrome (GBS) characterized by flaccid areflexive tetraplegia and signs of autonomic instability related to acute HIV-1 infection, and the occurrence of relapse episodes coinciding with the detection of HIV-1 RNA in blood during the phase of irregular treatment with antiretroviral agents. The patient has been asymptomatic for 3 years and has an HIV-1 load below the limit of detection. The recurrence of GBS in this case may be related to alterations of the immunologic response caused by disequilibrium in the host-HIV relationship due to the increase in HIV-1 viremia.
\end{abstract}

KEY WORDS: recurrent Guillain-Barré syndrome, HIV-1 infection, AIDS, acute demyelinating neuropathy.

\section{Episódios de Síndrome de Guillain-Barré associados com a fase aguda da infecção pelo HIV-1 e com recorrência da viremia}

RESUMO - É re p ortado um caso grave de Síndrome de Guillain-Barré (SGB) caracterizado por tetraplegia flácida arreflexa e sinais de instabilidade autonômica relacionado com infecção aguda pelo HIV-1, e a ocorrência de episódios de recidivas coincidentes com a detecção do RNA-HIV-1 no sangue, durante fases de tratamento irregular com antiretrovirais. O paciente encontra-se assintomático há 3 anos e com a carga viral do HIV-1 abaixo do limite de detecção. A ocorrência de SGB, neste caso, pode estar relacionada com alterações da resposta imunológica ocasionada por desequilíbrio na relação hospedeiro-HIV devido ao aumento da viremia do HIV-1.

PALAVRAS-CHAVES: sín drome de Guillain-Barré recorrente, infecção pelo HIV-1, AIDS, neuropatia desmielinizante aguda.

Guillain-Banésyndrome (GBS) is an acute peripheral polyneuropathy characterized by symmetrical muscle weakness occurring in the absence of identifiable causes of genetic, metabolic or toxic origin. There are some variants of the disease with distinct presentation, etiology and pathological characteristics, with the most common form being acute inflammatory demyelinating polyneuropathy, which represents about $75 \%$ of the cases of the syndrome ${ }^{1}$. The characteristic presentation of the syndrome involves symmetrical paresis or paresthesia of an ascending nature, with reduction or loss of deep reflexes and variable autonomic dysfunction. Examination of cerebrospinal fluid (CSF) reveals increased protein and normal or only slightly increased cellularity. The pathogenesis of GBS is not well known, but this is a disease with an important autoimmune component with cel- lular and humoral activity in which antibodies pro bably are more involved in the mechanism of demyelinization of peripheral nerves. The onset of the disease is associated with a history of infection, mainly of viral origin. There are several reports of the disease a ffecting HIV-infected patients, in which GBS occurs concomitantly with HIV seroconversion or during the initial phases of infection ${ }^{2-5}$. However, there are reports of the disease occurring also during the chronic phase ${ }^{6}$. There is evidence that GBS precedes acquired immunodeficiency syndrome (aids) and is not related to immunodeficiency, being usually observed in patients with high $\mathrm{CD} 4^{+}$lymphocyte counts. Cases of GBS associated with the immunological reconstitution induced by the use of highly active antiretroviral agents (ARV) have also been reported ${ }^{7}$. We did not detect reports of the occurrence of GBS related

Faculty of Medicine of Ribeirão Preto, University of São Paulo (FMRP-USP), Ribeirão Preto SP, Brazil: ${ }^{M}$ MD, Division of Tropical and Infectious Diseases, Department of Internal Medicine; ${ }^{2}$ Department of Neurology, Psychiatry and Medical Psychology.

Received 24 January 2006, received in final form 29 March 2006. Accepted 6 May 2006.

Dra. Gleusa de Castro - Divisão de Doenças Infecciosas e Tropicais / FMRP-USP - Avenida Bandeirantes 3900 - 14048-900 Ribeirão Preto SP - Brasil. E-mail: gcastro@hcrp.fmrp.usp.br 
to the plasma viral load of HIV-1. Recurrent GBS is a $r$ a re condition which has been re ported to occur at intervals ranging from 4 months to 10 years ${ }^{8}$, with the cases reported being unrelated to HIV.

We report, after written informed consent, a seve recase of GBS related to acute HIV infection with recurrent episodes coinciding with the detection of HIV viral load in blood during the phase of irregular treatment with ARV.

\section{CASE}

A previously healthy 38-year-old man presented pare sthesia and reduced evolutive ascending muscle strength in the lower limbs of 4 weeks duration, progressing to involvement of the upper limbs and abdomen, with impairment of locomotion and of arm movements.

He had a history of promiscuous homosexual behavior, although an anti-HIV ELISA test was negative during the month preceding the onset of symptoms. He presented diffuse micropolyadenomegaly, and neurological examination revealed an alert patient with sensitive ataxia and tactile painful hypesthesia up to the root of the thighs, and of the glove type up to the distal third of the forearms. Muscle strength was reduced bilaterally in the upper and lower limbs, with global areflexia. Meningeal signs were absent.

The ELISA test was repeated, with a positive result for anti-HIV-1 antibodies, as confirmed by Western blot. A CD4+ lymphocyte count showed 502 cells/ $\mu \mathrm{L}$ and the CSF contained 8 cells/ $/ \mathrm{L}, 194 \mathrm{mg} / \mathrm{dL}$ protein and $144 \mathrm{mg} / \mathrm{dL}$ glucose. At the time, the test for the quantitative determination of plasma HIV-1 RNA was not available. Electromyography revealed muscle action potentials with prolonged latencies, reduced conduction velocity with disperse morphology, partial block of peroneal nerve conduction and " $F$ " waves with prolonged or non-detectable latencies with no signs of axonal damage, findings corresponding to those observed in GBS.

Intravenous immunoglobulin (400 mg/kg/day) was administered for 5 days, leading to progressive improvement of the symptoms. Eight days after the end of this treatment the rewas recu rrence of the initial neurological picture accompanied by dysphagia, dysphonia and respiratory difficulty. Treatment with immunoglobulin was restarted, but the patient rapidly progressed to respiratoryinsufficiency, flaccid areflexive tetraplegia and autonomic instability characterized by hypertensive peaks, sudoresis, intestinal constipation and urine retention. Mechanical ventilation was necessaryand the immunoglobulin cycles were maintained, complemented with plasmapheresis sessions. ARV treatment (zidovudine, lamivudine and indinavir) was started. Electroneu romyography was repeated, revealing the absence of a response in the study of motor conduction of the median, ulnar and peroneal nerves. " $F$ " waves were not detected, suggesting severe axonal damage, with little evidence of re-innenation. A nerve biopsy was compatible with mild to moderate axonal damage. The patient was hospitalized in an intensive care unit for 4 months, present- ing a slow prog ressive improvement of signs and symptoms. At the time of discharge from the hospital he had 1045 CD4+ lymphocytes/ $\mu$ L blood and plasma HIV-1 RNA below the detection limit. During follow-up the patient recove red completely using ARV, always maintaining CD4 ${ }^{+}$ lymphocyte counts above $500 / \mu \mathrm{L}$ and HIV RNA below 50 copies $/ \mathrm{mL}$. Eighteen months after the acute signs and symptoms of GBS, he started to have reduced sensitivity and muscle strength of the extremities of the limbs. He had discontinued the use of ARV 15 days before due to episodes of renal lithiasis. On that occasion he had $570 \mathrm{CD} 4+$ lymphocytes/uLand 2600 copies/mL of HIV RNA (3.41 log). ARV were reintroduced but were changed to zidovudine, lamivudine and ritonavir due to renal lithiasis. The patient coursed with prog ressive and rapid improvement of the neurologic symptoms and the HIV-1 viral load became undetectable.

About 31 months after the first episode of GBS, the patient discontinued ritonavir due to intestinal intolerance. About 30 days later he started to present paresthesia and prog ressive ascending reduction of muscle strength in the limbs, with difficulty in walking. At that time the CD4 $4^{+}$lymphocyte count was $677 / \mu \mathrm{L}$ and HIV RNA was 380,000 copies/mL (5.59 log). HIV genotyping showed that the viru $s$ was sensitive to all ARV. CSF examination showed $1.5 \mathrm{cells} / \mu \mathrm{L}$ and a protein content of $72 \mathrm{mg} / \mathrm{dL}$. Electromyography was repeated and revealed alterations corresponding to GBS. The ARV scheme was replaced with zidovudine, lamivudine and efavirenz and treatment with immunoglobulin was started at weekly doses for about 6 months, with total recovery of movements and sensitivity. The patient has been asymptomatic for 3 years on the same antiretroviral scheme, with HIV-1 RNA below the detection limit.

\section{DISCUSSION}

Cell-mediated immunity is known to play an imp o rtant role in the pathogenesis of GBS. The characteristic initial stage of GBS is associated with demyelinization related to the action of macrophages, with multifocal distribution in the nerves. The main action of T cells appears to be the impairment of the integrity of the blood-nerve barrier by the action of metalloproteinases. T cells may also influence the recruitment of other cells of the immunologic response such as macrophages, Schwann cells and fibroblasts, resulting in the process of demyelinization. Biopsy and autopsy findings have been contradictory regarding the p resence or absence of perivascular lymphocyte infiltration in GBS. The fact that no lymphocytes are detected in nerves suggests that the changes mediated by antibodies are important, in agreement with the pathogenetic mechanism proposed for the onset of GBS, which occurs after infections, as is the case for Campylobacter jejuni infection?.

The mechanisms proposed for GBS in HIV-1-infected patients include a direct action of HIV-1 on the 
nerves by neuro tropic strains, or of autoimmune mechanisms, with the formation of antibodies against myelin secondary to the abnormal immunoregulation determined by HIV infection ${ }^{10}$.

The onset of GBS in this case coincided with the acute retroviral syndrome of HIV, during the phase of serologic conversion, as observed in other cases re ported in the literature ${ }^{5}$. Particularly interesting in the case in question was the fact that new episodes of GBS occurred during a late period in relation to the acute picture, with the two recurrence episodes coinciding with periods of exacerbation of HIV-1 viremia due to the interruption of ARV. This fact may suggest the occurrence of peculiar physiopathogenic mechanisms related to lack of control of viremia.

\section{REFERENCES}

1. Winer JB. Treatment of Guillain-Barré syndrome. Q J Med 2002; 95: 717721.
2. Millogo A, Sawadogo A, Lankoande D, Sawadogo AB. Guillain-Barré syndrome in HIV-infected patients at Bobo-Dioulasso Hospital (Burkina Faso). Rev Neurol (Paris) 2004;160:559-562.

3. Brannagan TH.3rd, Zhou Y.HIV-associated Guillain-Barré syndrome. J Neurol Sci 2003;208:39-42.

4. Thornton CA, Latif AS, Emmanuel, JC. Guillain-Barré syndrome associated with human immunodeficiency virus infection in Zimbabwe. Neurology 1991;4:812-815.

5. Kumar S, Alexander M, Markandeyulu V, Gnanamuthu C. GuillainBarré syndrome presenting in the anti-HIV seroconversion period. Neurol India 2003;51:559.

6. Bani-Sadr F, Neuville S, Crassard I, Guihot A; Molina JM. Acute Guillain-Barré syndrome during the chronic phase of HIV infection and dramatic improvement under highly active antiretroviral therapy. AIDS 2002;16:1562.

7. Makela P, Howe L, Glover S, Ferguson I, Pinto A, Gompels M. Recurrent Guillain-Barré syndrome as a complication of immune reconstitution in HIV. J Infect 2002;44:47-49.

8. Das A, Kalita J, Misra UK. Recurrent Guillain-Barré syndrome. Electromyogr Clin Neurophysiol 2004;44:95-102.

9. Willison HJ. The immunobiology of Guillain-Barré syndrome. J Peripher Nerv Syst 2005;10:94-112.

10. Dalakas MC, Pezeshkpour GH. Neuromuscular diseases associated with human immunodeficiency virus infection. Ann Neurol 1988;23: 38-45. 